\title{
Uma leitura das adaptações de Vidas Secas (1963) e A Hora da Estrela (1985) para o cinema
}

Maria Ignês Carlos Magno

Doutora em Ciências da Comunicação pela ECA-USP. Professora do Mestrado em Comunicação da Universidade Anhembi Morumbi.

E-mail: unsigster@gmail.com

Resumo: Por que histórias tão simples e conhecidas ainda provocam o leitor e o espectador? Como os autores olham e traduzem a realidade em imagens literárias? Como cineastas leem essas imagens literárias e as transformam em imagens cinematográficas? São perguntas que me levam a propor para essa resenha uma leitura dos arranjos que os autores e cineastas fizeram com as palavras e as imagens para que essas obras permaneçam atuais e provoquem o leitor e o espectador para que sejam sempre lidas, vistas e estudadas.

Palavras-chave: Cinema; Literatura; Clarice Lispector; Graciliano Ramos; Nelson Pereira dos Santos; Suzana Amaral.
Abstract: Why do such simple and wellknown stories still provoke the reader and the viewer? How do authors perceive and translate reality into literary images? How do filmmakers read these literary images and transform them into cinematographic images? All of these questions were responsible for this review: an analysis of the arrangements with words and images made by authors and filmmakers that transforms Vida Secas and A Hora da Estrela in up-todate works that always provoke the reader, the spectator and the researcher.

Keywords: Cinema; Literature; Clarice Lispector; Graciliano Ramos; Nelson Pereira dos Santos; Suzana Amaral.

A palavra não foi feita para enfeitar, brilhar como ouro falso; a palavra foi feita para dizer. (Graciliano Ramos)

A palavra tem que se parecer com a palavra. [...] E a palavra não pode ser enfeitada e artisticamente vã, tem que ser apenas ela. (Clarice Lispector)

A adaptação não é cadeia, é uma referência que faz chegar a grandes descobertas. Permanecer com estas referências - a essência do livro e sua estrutura narrativa é um grande estímulo que me leva a encontrar soluções que não desvirtuem nem ocultem o universo do autor. (Nelson Pereira dos Santos) 
[...] No meu caso, a minha preocupação era ser fiel a essa alma da obra. A Clarice diz assim: "o que me importa não são as palavras, é o sussurro por trás das palavras". Isso está no livro, e essa foi a minha preocupação na hora de filmar, na hora de encenar. (Suzana Amaral)

\section{INTRODUÇÃO}

Vidas Secas (1938) ${ }^{1}$, de Graciliano Ramos e A Hora da Estrela (1977)², de Clarice Lispector são dois livros transformados em filmes que têm, como personagens centrais, nordestinos pobres em retirada de seus lugares de origem. Esses se tornam conhecidos tanto na ficção quanto na história real. Fabiano sonhava com um lugar onde os filhos pudessem ter uma vida melhor, e esse lugar imaginado era a civilização. No livro, ficamos com o desejo de Fabiano já que ele e sua família não chegam à civilização. Macabéa também buscava na cidade grande uma vida melhor. O Rio de Janeiro foi a cidade escolhida, só que essa não lhe quis. E olha que o narrador se remoeu de vontade de dar a ela uma chance, pois "A única coisa que queria era viver. Não sabia para que, não se indagava”, mas queria viver, mesmo que fosse numa "cidade inconquistável".

Olhando para os títulos e a época em que as obras foram produzidas é impossível não nos perguntarmos por que, depois de tanto tempo, essas obras continuam atuais e provocadoras? Basta uma rápida pesquisa para encontrarmos centenas de artigos, resumos, dissertações, teses, críticas literárias e cinematográficas existentes sobre os livros e os filmes citados. No entanto, elas continuam, como Macabeus, martelando dentro de nós cada vez que retomamos esses livros ou seus filmes. Ver por que as imagens literárias e cinematográficas se complementam no específico de cada uma das expressões: a literatura e o cinema. Por que histórias tão simples e conhecidas ainda provocam o leitor e o espectador?

A despeito das inúmeras análises feitas das obras, tanto a literária quanto a cinematográfica, um aspecto me chama a atenção cada vez que para elas retorno: como os autores olharam e traduziram a realidade em imagens literárias e como os cineastas leram essas palavras e as transformaram em imagens cinematográficas. Pensando nisso gostaria de propor para essa resenha uma leitura dos arranjos que os autores e os cineastas fizeram com as palavras e as imagens na construção da narrativa para que essas obras permanecessem atuais e continuassem provocando o leitor e o espectador, garantindo que essas sejam sempre lidas, vistas e estudadas.

1. RAMOS, Graciliano. Vidas Secas. 130a ed. Rio de Janeiro: Record, 2016.

2. LISPECTOR, Clarice. A Hora da Estrela. Rio de Janeiro: José Olímpio, 1979.

\section{QUANDO O ROMANCE VIRA FILME. QUANDO O FILME PEDE O ROMANCE. VIDAS SECAS (1963) E A HORA DA ESTRELA (1985). APROXIMAÇÕES.}

Em 1938, Graciliano Ramos publica o romance Vidas Secas, que narra a saga de uma família de retirantes sertaneja: Fabiano, Sinha Vitória, os dois 
filhos meninos e a cachorra Baleia. Miseráveis, são obrigados a se deslocar para outros lugares sempre que a seca chega ao sertão.

Em 1977, Clarice Lispector publica A Hora da Estrela. O romance narra a história de Macabéa, uma jovem migrante nordestina que sonha em ser artista de cinema. Sai de Alagoas e vai para o Rio de Janeiro, sem preparo nenhum para enfrentar a cidade grande. A moça feia e solitária trabalha num escritório como datilógrafa e mora num quarto de pensão. $\mathrm{O}$ mundo chega até ela através de programas da rádio Relógio e comentários dispersos das pessoas que a cercam. Conhece casualmente o operário metalúrgico Olímpico de Jesus Moreira. Os dois nordestinos como "bichos da mesma espécie que se farejam”, começam um romance. Mas Glória, esperta colega de trabalho de Macabéa, rouba-lhe o namorado seguindo o conselho de uma cartomante, Madame Carlota. Macabéa faz uma consulta à mesma cartomante e esta prevê seu encontro com um homem rico, bonito e carinhoso.

Assim podemos sintetizar as duas obras. Sínteses que, ao mesmo tempo, nos fazem entender por que Graciliano Ramos definiu Vidas Secas como "um livrinho, sem paisagens, sem diálogos. E sem amor" — afinal, como ele dizia, seu romance não teria "tabaréus bem falantes, queimadas, cheias, poentes vermelhos, namoro de caboclos", e suas personagens, como ele descreve, eram "uma gente quase muda que vivia numa casa velha de fazenda; onde as pessoas adultas, preocupadas com o estômago, não tinham tempo de abraçar-se. Até a cachorra era uma criatura decente, porque na vizinhança não existia galãs caninos"- e por que Clarice, quando diz pela voz do narrador Rodrigo S.M: "Que ninguém se engane, só consigo a simplicidade através de muito trabalho. [...] Pensar é um ato. Sentir é um fato. Os dois juntos - sou eu que escrevo o que estou escrevendo"3 tinha certeza que "Essa narrativa mexerá com uma coisa delicada: a criação de uma pessoa inteira que na certa está tão viva quanto eu. Cuidai dela porque meu poder é só mostrá-la para que vós a reconheçais na rua, andando de leve por causa da esvoaçada magreza"4.

Essa gente e criatura que compõem o romance de Graciliano Ramos estavam ali bem próximas da vida e da memória do ficcionista. De acordo com o depoimento ao amigo João Condé, Sinha Vitória foi tomada da figura da avó, os meninos eram os tios pequenos - menino e menina - no romance, transformados em dois meninos, e o vaqueiro Fabiano tenha sido inspirado na figura do avô Pedro Ferro. Personagens construídos a partir das memórias, Fabiano é uma das criações mais fortes da ficção brasileira.

A personagem de Clarice, criada por inteiro na ficção, pode ser encontrada nas ruas de todas as cidades do Brasil. Como diz Rodrigo S.M ao falar da criação de sua personagem: "Como é que sei tudo que vai se seguir e que ainda o desconheço, já que nunca o vivi? É que numa rua do Rio de Janeiro peguei no ar de relance o sentimento de perdição no rosto de uma moça nordestina".

3. LISPECTOR, op cit. p. 15.

4. Idem, p. 24.

5. Idem, pp. 16-17. 
Dois ficcionistas que criaram, a partir da realidade, duas personagens referências da literatura brasileira: Fabiano e Macabéa. Referências porque são muitos os Fabianos e as Macabéas que encontramos todos os dias em diversos lugares seja na cidade ou no campo, isso é fato. Referências não só porque A Hora da Estrela é vista como continuação de Vidas Secas, mas porque essas duas personagens têm a palavra como o centro de suas reflexões. Palavras tão ocupadas pelas imagens que levaram os cineastas Nelson Pereira dos Santos (1963) e Suzana Amaral (1985) a transpor para a grande tela tais romances.

Nelson Pereira dos Santos e Suzana Amaral em épocas diferentes enfrentaram a difícil tarefa de adaptar os livros Vidas Secas e A Hora da Estrela para o cinema. Ambas as obras eram considerados quase intraduziveis para a linguagem cinematográfica. Graciliano conta em depoimento de 1944 que, ao ler um longo artigo de Octávio de Faria em que dissera "que o sertão, esgotado, já não dava mais romance", pensara: "Santo Deus! Como se pode estabelecer limitações para essas coisas? ”, e fez, como ele definiu, "um livrinho, sem paisagens, sem diálogos. E sem amor", completando que "talvez nisso esteja a originalidade da história". No caso da adaptação da obra para o cinema, é conhecida a afirmação do cronista Tristão de Ataíde sobre tal: "como acreditar na versão cinematográfica brasileira desse Machado de Assis do sertão, seco como uma queimada de agosto, com seu intencional estrangulamento emotivo e despojamento paisagístico?”.

Igual à afirmação feita por Octávio de Faria sobre um sertão, esgotado, que não daria mais romance, que levou Graciliano a escrever Vidas Secas e provar que era possível, a certeza de Tristão de Ataíde sobre a impossibilidade da adaptação da obra para o cinema levou Nelson Pereira dos Santos a provar o contrário em 1963.

Suzana Amaral não teve esse tipo de interferência na época em que adaptou a novela $A$ Hora da Estrela a não ser a mesma afirmação da dificuldade que era sua transformação para o cinema. Suzana não foi a primeira a adaptar Clarice para a linguagem cinematográfica - José Antonio Garcia juntamente com Ícaro Martins, um ano antes de A Hora da Estrela, adaptaram um texto da autora que resultou no longa-metragem Estrela Nua, outros contos como "A Via-Crucis do Corpo" (1991), ou "Felicidade Clandestina" (1998), adaptado por Denise Gonçalves, também servem de exemplo —, mas foi a primeira cineasta a conseguir passar na tela o que a autora imprimiu no papel e transformar Macabéa numa estrela de cinema reconhecida.

Segundo Ute Hermanns (1997), ao examinar a adaptação da novela

A Odisseia do Cinema Brasileiro: da Atlântida a Cidade de Deus. São Paulo: Companhia das Letras, 2016, p. 126.

7. HERMANNS, Ute. Literatura Mais Cinema: $\mathrm{Na}$ hora de filmar, esqueça o livro. Cinemais, n. 6, jul./ ago., 1997, p. 42.
A Hora da Estrela, é possível ver a influência que a literatura tem sobre o cinema, mas para desenvolver um texto fílmico, é preciso encarar outros aspectos. "Trata-se, como observa a diretora, de criar uma nova linguagem a partir de uma outra linguagem. Antes, é preciso ler, ler e reler o original. Mas na hora de filmar, o melhor é só pensar em cinema, buscar a atender às exigências particulares do cinema - e deixar o livro em casa"7. E foi o que a cineasta fez. Deixou o livro lido e relido em casa e "começou pela estória 
direto, [...] sem nenhuma intelectualização". "Eu queria contar a história eu mesma”, declarou Suzana em entrevista a LAFM (2008), sua preocupação era "manter-se fiel ao espírito do livro, à alma do livro, a essa coisa que me atraiu no livro. Não eram os fatos não, porque fatos eu mudava. Tanto que achei aquele negócio de escritor (o narrador da estória) era babaquice, uma especulação que também não me interessava estimular [...]".

Nelson não deixou o livro de lado, ao contrário, seguiu literalmente a história narrada por Graciliano. Sua preocupação também era ser fiel ao espírito do livro, "fazendo o possível para não alterar a estrutura narrativa que o autor elaborou. Isso porque a forma de contar uma história é determinada pela maneira de pensar", declarou em entrevista a Suzana Schild, em 1984. O cineasta, na mesma entrevista, explica como entende a construção de um roteiro. Para ele "a adaptação não é uma cadeia, é uma referência que faz chegar a grandes descobertas. Permanecer com estas referências - a essência do livro e sua estrutura narrativa - é um grande estímulo que me leva a encontrar soluções que não desvirtuem nem ocultem o universo do autor". Para Nelson: "Transformar um livro em filme significa recriar, em outra forma de expressão, o universo do autor". Formas de pensar e fazer a adaptação de um livro para o cinema. Maneiras diferentes de pensar para chegar a um resultado porque a construção de um roteiro a partir de um texto literário requer um trabalho bem rigoroso e, ao mesmo tempo, livre para a recriação de uma forma de expressão a outra. Suzana comprou os direitos do filme em 1982/83, demorou dois anos para adaptar o livro e só realizou o filme em 1985. Foram quatro versões de roteiros até chegar onde e como queria filmar novela. Nelson trabalhou no roteiro de 1958 a 1963, quando conseguiu filmar o romance da maneira como queria.

A liberdade de escolha e adaptação de uma obra literária passa pela relação que o cineasta tem com a obra escolhida e também com o autor dela. A identificação de Nelson Pereira dos Santos era política e social, e a escolha de Vidas Secas, como relatou em entrevista a Alberto Shatovsky (1963), deu-se, entre outros motivos, porque,

Nenhum outro dos nossos romancistas tinha tão grande senso dos valores dramáticos, nem uma penetração psicológica tão admirável e segura. Os personagens que ele criou não eram títeres, criaturas inventadas, simples sombras saídas da imaginação de um ficcionista. Eram, ao contrário, seres vivos, de carne e osso, sangue e nervos, com reações lógicas e atos que obedeciam, sempre, a motivações profundas. Não há tipos inconsequentes ou artificiais em seus livros. Por isso mesmo, eles seduzem a imaginação de um cineasta [...].

Suzana era leitora de Clarice, lera todos seus livros. Considerava, como muitos, a autora uma burguesa cujas personagens e preocupações estavam ligados à classe média, e reconhecia que A Hora da Estrela era o primeiro livro em que tratou dos problemas de uma personagem pobre. Explica que a escolha do livro não estava no fato de Macabéa ser pobre, mulher e coitadinha. Diz em entrevista:
8. SALEM, Helena. Nelson Pereira dos Santos: o sonho possível do cinema brasileiro. Rio de Janeiro: Editora Nova Fronteira, 1987, p. 172. 
Escolhi a Macabéa, não porque ela é coitadinha, porque é mulher. Eu a escolhi porque é um problema de comunicação principalmente [...]. A Clarice nunca tinha feito um livro social: foi a sua primeira aventura social. [...]. Este é o primeiro livro em que de repente faz uma tentativa - a meu ver bem-sucedida porque ela conseguiu - de captar a impotência, a passividade, a impossibilidade do diálogo, a falta de repertório. (Entrevista dada a LAFM, 2008.)

Não é o caso de discutir aqui a fala de Suzana sobre o "nunca ter feito um livro social" e as relações de classe. O que interessa nesse momento é a visão de Suzana sobre o que considera central na obra e personagem: o problema da "comunicação" e o "captar a impotência, a passividade, a impossibilidade do diálogo, a falta de repertório" da Macabéa de Clarice. E sua aproximação com o Fabiano de Graciliano se torna inevitável, assim como a aproximação de Clarice e Graciliano, já que para ambos o centro do problema está na palavra. Escreve Rodrigo S.M:

Sim, mas não esquecer que para escrever não-importa-o-quê o meu material básico é a palavra ${ }^{9}$.

Tudo isso, sim, a história é história. Mas sabendo antes para nunca esquecer que a palavra é fruto da palavra. A palavra tem que se parecer com a palavra. Atingi-la é o meu primeiro dever para comigo. E a palavra não pode ser enfeitada e artisticamente vã, tem que ser apenas ela ${ }^{10}$.

Exatamente como Graciliano ao falar sobre o ofício do escritor na contracapa da edição de Vidas Secas aqui trabalhada.. Dizia que quem se mete a escrever devia fazer como as lavadeiras de Alagoas faziam seu ofício:

Elas começam com uma primeira lavada, molham a roupa suja na beira da lagoa ou do riacho, torcem o pano, molham-no novamente, voltam a torcer. Colocam o anil, ensaboam e torcem uma, duas vezes. Batem o pano na laje ou na pedra limpa, e dão mais uma torcida e mais outra, torcem até não pingar do pano uma só gota. Somente depois de feito tudo isso é que dependuravam a roupa para secar. Pois quem se mete a escrever devia fazer a mesma coisa. A palavra não foi feita para enfeitar, brilhar como ouro falso; a palavra foi feita para dizer.

A palavra ausente das personagens e a impossibilidade do diálogo, da comunicação, os sentidos das palavras para as personagens e o ofício do escritor no talhar as palavras na feitura de uma obra - isso interessava aos autores e nos interessa acompanhar como tais aparecem nas obras literárias e como foram transportadas para o cinema.

9. LISPECTOR, op. cit., p. 19.

10. Idem, p. 25.

\section{PERSONAGENS E NARRADORES - AS VOLTAS COM} AS PALAVRAS

A preocupação e a sedução das palavras que acompanham Fabiano e Macabéa também eram caras aos narradores das histórias. Rodrigo S.M, antes de iniciar a história da nordestina, justificava que a "história será feita de palavras que se agrupam em frases e destas se evola um sentido secreto 
que ultrapassa palavras e frases". E para isso tinha "então que falar simples para captar a sua delicada e vaga existência"11. Antes, porém, de se limitar a "contar as fracas aventuras de uma moça numa cidade toda feita contra ela”, afiançava "que essa moça não se conhece senão através de vivendo à toa. Se tivesse a tolice de se perguntar 'quem sou eu?' cairia estatelada e em cheio no chão. É que‘quem sou eu’ provoca necessidade. E como satisfazer a necessidade/ quem se indaga é incompleto"12.

O narrador da história dos nordestinos retirantes também apresentou a família como "seres quase mudos, numa viagem que prosseguia mais lenta, mais arrastada, num silêncio grande" e Fabiano um bruto. "Vivia longe dos homens, só se dava bem com os animais"13. Mas, ao contrário de Macabéa, questionava sua existência. E numa conhecida reflexão, Fabiano diz: "você é um homem, exclamou em voz alta. Conteve-se, notou que os meninos estavam perto, com certeza iam admirar-se ouvindo-o falar só. E pensando bem ele não era um homem, era apenas um cabra ocupado em guardar as coisas dos outros [....] olhou em torno, com receio de que, fora os meninos alguém tivesse percebido a frase imprudente. Corrigiu-a, murmurando: Você é um bicho Fabiano"14.

Macabéa admirava as palavras. Conta Rodrigo S.M. que "Havia coisas que não sabia o que significavam. Uma era 'efeméride'. E não é que seu Raimundo só mandava copiar com sua letra linda a palavra efemérides ou efeméricas? Achava o termo efemérides absolutamente misterioso. Quando o copiava prestava atenção a cada letra. [...] Enquanto isso, a mocinha se apaixonara pela palavra efemérides" ${ }^{15}$. Fabiano falava pouco "mas admirava as palavras compridas e difíceis da gente da cidade, tentava reproduzir algumas, em vão, mas sabia que eram inúteis e talvez perigosas"16. Admirava seu Tomás da bolandeira que sabia ler, tinha o domínio das palavras, uma sabedoria que inspirava respeito. E em horas de maluqueira Fabiano desejava imitá-lo: "dizia palavras difíceis, truncando tudo, e convencia-se de que melhorava. Tolice. Viu-se perfeitamente que um sujeito como ele não tinha nascido para falar certo"17. Mas, ambos os narradores sabiam que as palavras eram perigosas porque se as pessoas aprendessem qualquer coisa, necessitariam aprender mais, e nunca ficariam satisfeitos. "Fabiano dava-se bem com a ignorância. Tinha o direito de saber? Tinha? Não tinha"18. Macabéa dava-se bem com sua ignorância, mas gostava de aprender palavras novas. Aprendia com o rádio. Todas as noites ligava o aparelho emprestado por uma colega de moradia, Maria da Penha, bem baixinho para não acordar as outras moças, invariavelmente para a Rádio Relógio que dava "hora certa e cultura".

Duas personagens que amavam e se debatiam com e pelas palavras na difícil tarefa de se comunicar, defender-se, existir por inteiro. Basta recuperarmos a ruminação de Fabiano quando estava na cadeia e acordou sobressaltado.

Pois estava misturando as pessoas, desatinado? Ouviu o falatório desconexo do bêbado, caiu numa indecisão dolorosa. Ele também dizia palavras sem sentido, conversas à toa. Irou-se com a comparação. Então mete-se um homem na cadeia porque ele não sabe falar direito? Que mal fazia a brutalidade dele? Tinha culpa

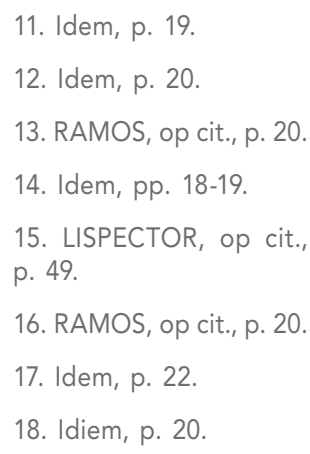


19. Idem, p. 35 .

20. LISPECTOR, op. cit. p. 17.

21. Idem, p. 48.

22. CANDIDO, Antonio. Ficção e Confissão: Ensaios sobre Graciliano Ramos. Rio de Janeiro: Ouro sobre Azul, 2012, p. 40.

23. Idem.

24. Idem, p. 86

25. Idem, p. 23

26. Idem, p. 82

27. Idem, p. 23 de ser bruto? [...] Nunca vira uma escola. Por isso não conseguia defender-se, botar as coisas nos seus lugares. [...] Se lhe tivessem dado ensino, encontraria meio de entendê-la. Impossível, só sabia lidar com bichos [...] Pensava em seu Tomás que lhe daria explicações. Era homem aprendido. Mas [...] cada qual como Deus o fez. Ele, Fabiano, era aquilo mesmo, um bruto ${ }^{19}$.

E o conflito do narrador para falar da personagem nordestina, querer lhe dar voz, mas não consegue e explica sua dificuldade:

Não se trata apenas de narrativa, é antes de tudo vida primária que respira, respira, respira ${ }^{20}$.

Tornara-se com o tempo apenas matéria vivente em sua forma primária. [...] Era apenas matéria orgânica. Existia. Só isso ${ }^{21}$.

Fabiano e Macabéa existiam, simplesmente. Mas e apesar de existirem simplesmente, eram puros em seus íntimos. Fabiano, segundo Antonio Candido ${ }^{22}$ "é esmagado, pelos homens e pela natureza; mas seu íntimo de primitivo é puro". Para Macabéa. "Por pior que fosse sua situação, não queria ser privada de si, ela queria ser ela mesma."23. "Tinha pensamentos gratuitos e soltos porque embora à toa possuía muita liberdade interior" ${ }^{24}$. Enquanto as personagens viviam às voltas com as palavras e suas existências primárias, a preocupação com as palavras e os sentidos das palavras é tamanha entre os narradores que podemos aproximá-los quando lemos o questionamento de Rodrigo S.M ${ }^{25}$ : "Será mesmo que a ação ultrapassa a palavra? Mas que ao escrever - que o nome real seja dado às coisas. Cada coisa é uma palavra. E quando não se a tem, inventar-se-á. Esse vosso Deus nos mandou inventar". Como os meninos na festa de Natal da cidade, "ocupando-se em descobrir uma enorme quantidade de objetos". Diante das lojas, "puseram-se a discutir a questão intrincada. Como podiam os homens guardar tantas palavras? Era impossível, ninguém conservaria tão grande soma de conhecimentos. Livres dos nomes, as coisas ficavam distantes, misteriosas" ${ }^{\prime 2}$. Sobre a procura e a busca das palavras para descrever as personagens e suas histórias, questionavam-se sobre o ofício do escritor. Por que escrevo? Perguntava-se Rodrigo S.M.?. "Antes de tudo porque captei o espírito da língua e assim às vezes a forma é que faz o conteúdo"27.

Captar o espírito da língua, era a tarefa dos autores, captar o espírito das obras para transformá-las em filmes, era a tarefa dos cineastas. Captar como os cineastas leram as imagens e trabalharam a forma para fazer o conteúdo dos filmes é nossa proposta.

\section{NELSON E SUZANA - AS VOLTAS COM A RECRIAÇÃO DAS PALAVRAS LITERÁRIAS EM IMAGENS CINEMATOGRÁFICAS}

A palavra foi feita para dizer. A palavra tem que se parecer com a palavra. A imagem também. Pois quem se mete a fazer cinema precisa saber tratar as 
imagens como o escritor a palavra. O contrário também. Nelson Pereira dos Santos e Suzana Amaral têm a consciência do ofício de cineastas, sabem talhar as imagens com a precisão das lavadeiras das Alagoas, além de saberem o quanto a composição literária de Graciliano e Clarice está impregnada de imagens cinematográficas.

Desde os anos 1930-40, cinema e literatura passam não só a conviver, mas inspiram-se e exercem influências mútuas. O cinema, inspirando-se no romance, privilegiou os filmes narrativos e o romance, inspirando-se no cinema, passou a utilizar uma série de expedientes cinematográficos, como a simultaneidade de ação, a sucessão de planos, o close-up etc. De acordo com Massaud Moisés, desse convívio entre as obras literárias e o cinema, surge, no romance, duas manifestações artísticas:

Resultou a certeza de haver uma especificidade literária e uma especificidade cinematográfica: ao transpor o romance para a tela, o diretor introduz mudanças no texto a fim de adaptá-lo às contingências emprega recursos do cinema, integra-os na sua própria natureza: propõe a imaginação do leitor no ato de reconstruir personagens e cenas, enquanto o cinema mostra ao espectador ${ }^{28}$.

Essa certeza do específico literário e fílmico e a consciência de que a transposição da obra literária para a tela necessitaria de mudanças no texto para adaptá-los às contingências do cinema, faz com que os cineastas exercitassem e, por isso mesmo, lessem e adaptassem as obras seguindo estratégias diferentes. Nelson Pereira dos Santos optou pela fidelidade ao texto e Suzana Amaral optou por partir da obra e contar a história por ela mesma. Daí, por exemplo, ter excluído o narrador e partido direto para história, justificou na entrevista a LAFM, em 2008. Nelson também justificou sua opção: dizia que sua fidelidade era à essência e à estrutura narrativa da obra. Não era uma simples transposição do texto literário para o cinema, ainda que o livro já fosse uma espécie de roteiro, com posição de câmera inclusive: "Fabiano agachou, pegou a cuia ...bebe ...olhou e viu os beiços secos de Sinha Vitória. O plano está feito - a câmera começa em Fabiano, e depois, de baixo para cima, focaliza Sinha Vitória”, exemplifica na entrevista dada a Suzana Schild, em 1984.

Necessidade de introduzir mudanças no texto para as contingências do cinema e liberdade de criação porque, "transformar o livro em filme significa recriar, em outra forma de expressão, o universo do autor”, reforçava Nelson Pereira a Helen Salem (1995). Para os cineastas, recriar uma obra literária para o cinema não significava ausência de liberdade para sua própria criação, justamente porque literatura e cinema são formas de expressão específicas e requerem o domínio da linguagem sobre a qual trabalham e a sensibilidade para a apreensão da essência da obra a ser transformada em outra.

Quando retomamos os textos literários, os depoimentos sobre os processos de escrita dos contos que deram origem ao romance Vidas Secas e a novela $A$ Hora da Estrela, quando lemos o que foi escrito sobre as adaptações que Nelson Pereira e Suzana Amaral fizeram as obras para o cinema, temos o entendimento
28. MOISÉS, M. Dicionário de Termos Literários. São Paulo: Cultrix, 2004, p. 403. 
dos processos e das teorias sobre adaptação, mas quando voltamos às obras compreendemos não só os elementos compositivos dos processos de criação, como enxergamos as aproximações entre texto literário e cinematográfico, o convívio, as influências e a depuração dos processos técnicos da literatura e do cinema.

De Vidas Secas, um "romance desmontável” porque as cenas e os episódios foram escritos mais ou menos isolados e depois arrumados — ou seja, montado para ser transformado em romance, igual à montagem de cenas e sequências de um filme para narrar uma história —, vale tomar o primeiro capítulo "Mudança" como um exemplo das influências, do convívio entre cinema e literatura e da criação no processo de adaptação.

Assim Graciliano inicia a saga da família na geografia do sertão:

Na planície avermelhada os juazeiros alargavam duas manchas verdes. Os infelizes tinham caminhado o dia inteiro, estavam cansados e famintos. Ordinariamente andavam pouco, mas como haviam repousado bastante na areia do rio seco, a viagem progredira bem três léguas. Fazia horas que procuravam uma sombra. A folhagem dos juazeiros apareceu longe, através dos galhos pelados da caatinga rala. [...] Os juazeiros aproximavam-se, recuaram, sumiram-se. [...] A caatinga estendia-se, de um vermelho indeciso salpicado de manchas brancas que eram ossadas. O voo negro dos urubus fazia círculos altos em redor de bichos moribundos.

E, assim, Nelson Pereira dos Santos inicia seu filme. Uma narração que faz doer os olhos que acompanham, na tela do cinema, a descrição da planície, a miséria e a viagem daquela gente quase muda. Descrição e imagem tornadas antológica tanto na literatura como no cinema brasileiro. O romance, sob o impacto que o cinema teve sobre a ficção, aprendeu a lição que lhe alterou o futuro: a de "que quanto menos se diz, melhor é, que os efeitos estéticos mais impressionantes nascem do encontro de duas imagens sem comentário algum [...]"29. O olho do cineasta enxergou as imagens coloridas descritas no romance e criou, em preto e branco, uma das sequências mais bonitas do cinema brasileiro. Glauber Rocha ${ }^{30}$ ao falar sobre o significado de Vidas Secas para o cinema brasileiro escreveu:

Luiz Carlos Barreto concebeu para Vidas Secas uma fotografia direta: captar o sol do nordeste, sua ação na paisagem e nos homens. Comidos pelo sol, os personagens se deslocam inicialmente na caatinga plana e vasta. A cena de abertura propõe um novo tipo de cinema. Os personagens se movem ao longe e se aproximam lentamente do espectador, na frente a cachorra Baleia. Como som se ouve apenas o ranger de um carro de boi. [...] O filme se desenrola nesta proposição. Os quadros brancos e luminosos se sucedem monotonamente, mas cada um deles revela meditar (sic) sobre o que vê se irrita: se o próprio Fabiano-herói não faz nada para mudar essa situação, só chega mesmo a fugir quando a seca se torna mortal.

1948 , p. 59.

30. ROCHA, G. O Cinema novo e a aventura da criação [1968]. In: Revolução do Cinema novo. Rio de Janeiro: Alhambra/ Embrafilme, 1981, p. 108.

O trabalho com a imagem passava pela captação do que Nelson Pereira entendia "como a verdadeira luz do Nordeste". Uma fotografia sem filtros, o mínimo de iluminação, o mais natural possível, "dando o diafragma pela luz do rosto, de modo que tudo que vem atrás aparece estourado, aquele 
branco, transmitindo a sensação de luz ofuscante, de temperatura alta, da seca, do ambiente da caatinga" ${ }^{31}$. O silêncio das personagens se deslocando naquela paisagem seca, angustiante, também foi cuidadosamente trabalhada para não alterar a sensação causada pela descrição literária. De acordo com o crítico de cinema José Lino Grünewald ${ }^{32}$, Nelson Pereira, a fim de proporcionar efeitos cinematográficos análogos aos do romance, "foi buscá-lo mediante uma apropriação muito feliz, consciente ou intuitiva, daquilo que já se denominou como os tempos mortos, criados por Michelangelo Antonioni [...]". Nesse exercício de recriar o romance, de transformar a narrativa literária em cinematográfica, Nelson Pereira dos Santos conseguiu, segundo Jean-Claude Bernardet ${ }^{33}$, "o mais alto grau de abstração atingido entre nós pelo cinema”.

Outro exemplo em que o encontro entre duas formas de expressão específicas nos permite ver as influências, a convivência e, principalmente, a depuração dos processos técnicos do romance e do filme está no capítulo "Inverno", que no livro é o sétimo capítulo e na sequência fílmica é a segunda, mostra porque o romance, ao empregar recursos do cinema, integrando-o na sua própria natureza, propõe a imaginação do leitor no ato de reconstruir personagens e cena, conforme o cinema mostra ao espectador. Vale a transcrição de alguns trechos:

A família estava reunida em torno do fogo. Fabiano sentado no pilão caído, sinha Vitória de pernas cruzadas, as coxas servindo de travesseiros aos filhos. A cachorra Baleia, com o traseiro no chão e o resto do corpo levantado, olhava as brasas que se cobriam de cinza. [...] Fabiano esfregou as mãos satisfeito e empurrou os tições com a ponta da alpercata. As brasas estalaram, a cinza caiu, um círculo de luz espalhou-se em redor da trempe de pedra, clareando vagamente os pés do vaqueiro, os joelhos da mulher e os meninos deitados. [...] Quando iam pegando no sono, arrepiavam-se, tinham precisão de virar-se, chegavam-se à trempe ou ouviam a conversa dos pais. Não era propriamente uma conversa: eram frases soltas, espaçadas, com repetições e incongruências. Às vezes uma interjeição gutural dava energia ao discurso ambíguo. Na verdade nenhum deles prestava atenção às palavras do outro: iam exibindo as imagens que lhes vinham ao espírito, e as imagens sucediam-se, deformavam-se, não havia meio de dominá-las ${ }^{34}$.

Suzana não segue a risca a estrutura da novela A Hora da Estrela. Embora a preocupação central fosse a de ser fiel à alma do livro, olhou para a história de maneira diferente. O roteiro foi elaborado a partir da obra, sem o compromisso de traduzir todos os elementos que a compõem. Por exemplo, a eliminação do narrador Rodrigo S.M. Conforme declarou na entrevista a LAFM: "tirei o narrador, porque achei que o narrador era chato". É claro que dito assim parece gratuito, mas não é. A sua forma de pensar e de fazer cinema é outra. Na mesma entrevista explica: "Você tem que estabelecer qual é o seu enfoque. Porque um filme é como se fosse uma espinha de peixe: tem que ter um eixo central e depois os fatos, que são as espinhas laterais; aquilo que fica no meio da estrutura. Esta estrutura, essa coisa grossa do meio é a linha central, é o
31. SALEM, op. cit., p. 164.

32. 1963 , p. 129.

33. BERNARDET, JeanClaude. Bernardet, J.C. Brasil em Tempo de Cinema. Rio de Janeiro: Editora Civilização Brasileira, 1967.

34. Idem, pp. 63-64. 
que você tem em vista, o que você quer comunicar, quer dizer. Então, todas as ações precisam remeter ao espírito central da obra, à alma”. Rearranjo textual para criar as imagens como ela visualizou, sem perder a essência da obra.

Retomando filme e livro, percebemos que apesar de ela ter dito que tirou o narrador porque achava ele chato, redesenhou a história pelas palavras dele. Reorganizou as palavras e as imagens para contar a história de Macabéa com olhos próprios. Pegando pelas palavras para exemplificar, Suzana diz que o filme é simples. Esse era o desejo do narrador quando diz:

Pretendo, como já insinuei, escrever de modo cada vez mais simples. Aliás, o material de que disponho é parco e singelo demais, as informações sobre os personagens são poucas e não muito elucidativas, informações essas que penosamente me vêm de mim para mim mesmo, é trabalho de carpintaria.

Trabalho de carpintaria do narrador da história e da cineasta porque o material de que dispunham "é parco e singelo demais". Macabéa. E Rodrigo S.M continua: "Embora a moça anônima da história seja tão antiga que podia ser uma figura bíblica. Ela era subterrânea e nunca tinha tido floração. Minto: ela era capim"35. Grande exemplo é o trecho em que Macabéa bate na porta da cartomante ${ }^{36}$ : "Pensou vagamente enquanto tocava a campainha da porta: capim é tão fácil e simples”.

Trabalho de carpintaria para o narrador que considerava a escrita difícil, principalmente quando a história era simples demais ${ }^{37}$ :

Não, não é fácil escrever. É duro como quebrar rochas. Mas voam faíscas e lascas como aços estilhados. Ah que medo de começar e ainda nem sequer sei o nome da moça. Sem falar que a história me desespera por ser simples demais. O que me proponho a contar parece fácil e à mão de todos. Mas a sua elaboração é muito difícil.

Pintura para a cineasta que entendeu a simplicidade da história e foi desenhando as personagens, rearranjando os diálogos e só depois de se tornar íntima delas, transformou as palavras em imagens cinematográficas. Um exemplo disso pode ser lido no texto do crítico Cássio Starling Carlos ${ }^{38}$ :

Um gato isolado mastiga restos num cenário cheio de caixas como um depósito. Um movimento de câmera para a esquerda e para cima mostra uma moça sozinha, sentada à mesa diante de uma máquina de escrever. Bastam ver esses elementos na cena para nos darmos conta de como o cinema, tanto quanto as palavras, produz significados. Ali, antes de qualquer texto, na forma de diálogo ou de pensamento em voz alta, somos postos diante dessa não existência, da "história de uma inocência pisada, de uma miséria anônima", como descreveu Clarice Lispector numa entrevista a respeito do livro.

Não sendo crítica para explicar dessa maneira as relações entre texto e imagem, mas entendendo outras relações que tanto textos como imagens permitem, gostaria de retomar alguns trechos da obra literária e mostrar como a cineasta se relacionou com as palavras para criar as imagens cinematográficas. 
Rodrigo S.M. igual ao poema "A Passante" de Baudelaire, "numa rua do Rio de Janeiro peguei no ar de relance o sentimento de perdição no rosto de uma moça nordestina" ${ }^{39}$, e se apaixonou: "Eu não inventei essa moça. Ela formou-se dentro de mim a sua existência”, embora tenha se apaixonado por ela na página 37, na página 36 ele descreve a sua morte. A morte da estrela.

Assim como ninguém lhe ensinaria que um dia a morrer: na certa morreria um dia como se antes tivesse estudado de cor a representação do papel de estrela. Pois na hora da morte a pessoa se torna brilhante estrela de cinema, é o instante de glória de cada um e é quando como um canto coral se ouvem agudos sibilantes.

Morte que acontece após a visita à cartomante Madame Carlota. Embora o narrador afirme que descrever cansa, e a cineasta afirme que o narrador é chato, Rodrigo S.M começa a descrição da morte de Macabéa e a de si mesmo na página 86. Suzana segue a descrição do narrador para compor o final do filme. Impossível não seguir o narrador e a força das imagens na narração. Quase um roteiro:

Saiu da casa da cartomante aos tropeços e parou no beco escurecido pelo crepúsculo - crepúsculo que é hora de ninguém. Mas ela de olhos ofuscados como se o último final da tarde fosse mancha de sangue e ouro quase negro. [...] Macabéa ficou um pouco aturdida sem saber se atravessaria a rua pois sua vida já estava mudada. E mudada por palavras. [...] Então ao dar o passo de descida da calçada para atravessar a rua, o Destino sussurrou veloz e guloso: é agora, é já, chegou a minha vez! [...] Batera com a cabeça na quina da calçada e ficara caída, a cara mansamente voltada para a sarjeta. E da cabeça um fio de sangue inesperadamente vermelho e rico. [...] Ficou inerme no canto da rua, talvez descansando das emoções, e viu entre as pedras do esgoto o ralo capim de um verde da mais tenra esperança humana. Hoje, pensou ela, hoje é o primeiro dia de minha vida: nasci.

Na luta do narrador consigo mesmo oscilava entre a alegria de "que ainda não chegou a hora da estrela de cinema de Macabéa morrer" ou a morte da menina-infante. Mas ela ainda estava viva. "Tanto estava viva que se mexeu devagar e acomodou o corpo em posição fetal. Grotesca como sempre fora. Aquela relutância em ceder, mas aquela vontade do grande abraço. Ela se abraçava a si mesma com vontade do doce nada" ${ }^{40}$. Então continua o narrador "ali deitada - teve uma úmida felicidade suprema, pois ela nascera para o abraço da morte". Quase um roteiro em que as palavras e as imagens se entrelaçam numa poesia que enche os olhos quando lemos a novela ou quando vemos o filme. Sabemos que o narrador não é o autor. Ele pode até ser lido como uma projeção de um dos eus do autor. Mas não é o autor. Macabéa não é Clarice, Fabiano não é Graciliano, ou o contrário. Particularmente gosto dos narradores porque é por meio deles que percebemos o exercício da escrita, a "doma da palavra" para conseguir domar a si mesmo e captar a alma da personagem na condução da história.

Depois de reler as obras e assistir aos filmes é possível entender as sugestões do poeta Manuel de Barros e do cineasta Nelson Pereira dos Santos.

39. LISPECTOR, op. cit., pp. 16-17.

40. Idem, p. 100 
comunicação \& educação • Ano XXII • número 1 • jan/jun 2017

Manuel de Barros sugere: "Para fazer poesia - uma amarração de objetos lúdicos com emprego de palavras, de imagens, de cores, sons etc., - convém passar os olhos pelo cinema" ${ }^{41}$. Porque "imagens são palavras que nos faltaram. Poesia é a ocupação da palavra pela imagem”. Para fazer cinema, - "um cinema ligado ao povo, que libere o povo brasileiro no sentido de apurar o seu comportamento não dependente de um modelo prescrito por outra sociedade - convém primeiro passar os olhos pela literatura", sugere Nelson Pereira dos Santos ${ }^{42}$.

Imagens ocupadas pela palavra. Palavras que tanto seduziam Fabiano e Macabéa. Se entendemos que "para a construção da realidade e o conhecimento dela, o homem, entre outras coisas, apropria-se dos sentidos das palavras, dos signos, reelaborando-os" ${ }^{\prime 3}$, podemos dizer que tanto Nelson Pereira dos Santos como Suzana Amaral, ao se apropriarem das palavras, reelaboraram e transformaram aquelas palavras/imagens literárias em imagens cinematográficas. Imagens e palavras ocupando-se, dando-se em constante movimento.

\section{REFERÊNCIAS BIBLIOGRÁFICAS}

AVELLAR, José Carlos. O Chão da Palavra. Rio de Janeiro: Rocco, 2007.

BERNARDET, Jean-Claude. Bernardet, J.C. Brasil em Tempo de Cinema. Rio de Janeiro: Editora Civilização Brasileira, 1967.

BACCEGA, Maria Aparecida. Palavra e discurso. História e Literatura. São Paulo: Ática, 1995.

CANDIDO, Antonio. Ficção e Confissão: Ensaios sobre Graciliano Ramos. Rio de Janeiro: Ouro sobre Azul, 2012.

CARLOS, Cássio Starling. Invisibilidade de Macabéa torna-se mais perceptível no cinema. In: Coleção Clássicos do Cinema, Folha de S. Paulo, 2013.

DESBOIS, Laurent. A Odisseia do Cinema Brasileiro — Da Atlântida a Cidade de Deus. São Paulo: Companhia das Letras, 2016.

GRÜNEVALD, J.L. "Vidas Secas”, In Castro, R. (ED), Um Filme É Um Filme. O Cinema de Vanguarda dos anos 69. São Paulo: Companhia das Letras, 1963.

HERMANNS, Ute. Cinemais, julho/ago. 1997. In: Coleção Folha Grandes Livros no Cinema, 2013.

41. AVELLAR, José Carlos. O Chão da Palavra. Rio de Janeiro: Rocco, 2007, p. 38.

42. Idem, p. 5.

43. BACCEGA, Maria Aparecida, Palavra e discurso. São Paulo: Ática, 1995 , p. 36.
LAFM, Entrevista com Suzana Amaral. In: Araújo, Washington Luís Andrade de. Macabéa vai ao Cinema. A Hora da Estrela e a Travessia da Linguagem Literária para a Cinematográfica. Dissertação de Mestrado apresentada na UnB, Brasília-DF, em 2008.

LISPECTOR, Clarice. A Hora da Estrela. Rio de Janeiro: José Olímpio, 1979. MOISÉS, Massaud. Dicionário de Termos Literários. São Paulo: Cultrix, 2004. 
RAMOS, Graciliamos. Vidas Secas. Rio de Janeiro: Editora Record, 2016.

ROCHA, Glauber. O Cinema novo e a aventura da criação [1968]. In:

Revolução do Cinema novo. Rio de Janeiro: Alhambra/Embrafilme, 1981.

SALEM, Helena. Nelson Pereira dos Santos: o sonho possível do cinema brasileiro. Rio de Janeiro: Editora Nova Fronteira, 1987.

SANTOS,Nelson Pereira. Entrevista a Alberto Shatovsky, Revista Manchete, 1963.

"A arte de recriar", entrevista a Suzana Schild, Revista IBM, n.18, setembro, 1984.

\section{FILMOGRAFIA}

Vidas Secas (1963)

Roteiro e Direção — Nelson Pereira dos Santos

Extraído do romance de Graciliano Ramos

Gênero - Ficção

Fotografia - Luís Carlos Barreto e José Rosa

Cenografia - João Duarte

Montagem- Rafael Justo Valverde

Música - Leonardo Alencar

Letra - Lígia Pape

Produção - Luís Carlos Barreto, Herbert Richers e Danilo Trelles

Duração - 103 min

\section{A Hora da Estrela (1985)}

Argumento e Roteiro - Suzana Amaral e Alfredo Oroz

A partir da obra homônima de Clarice Lispector

Gênero - Ficção

Fotografia - Edgar Moura

Cenografia - Clóvis Bueno

Música - Marcus Vinicius

Montagem — Idê Lacreta

Direção de Arte - Clóvis Bueno

Produção - Assunção Hernandes

Duração — 96 min 